\title{
Students' Perceptions of English Creative Writing Using the Weblogs
}

\author{
Yanto Yanto $^{1 *}$, Nurul Fajria², Tubagus Zam Zam Al Arif ${ }^{3}$
}

\author{
${ }^{123}$ Faculty of Teacher Training and Education, Universitas Jambi \\ *Corresponding Author. Email: yanto.fkip@unja.ac.id
}

\begin{abstract}
This research aimed to understand student's perception toward the use of weblogs and how weblogs help them in improving their writing skills, also investigate the positive aspects and barriers occur in the learning. This study used a mixed-methods design, in which the data were collected through online questionnaires and interviews. The participants of this study were the students of the Introduction to Creative Writing subject batch 2017. The result of the study showed that students' perception of writing on the weblog is positive, and proven to improve their writing and reading skills. The result also showed that confidence and motivation in writing for the public also increased. Moreover, the weblog delivered the most positive aspects in vocabulary. Besides its benefits, some students still had difficulties in writing using the weblog, such as internet connection problems. Although the use of this technology in improving teaching and learning in writing claimed beneficially, teachers still need to guide the students to use the weblog and the students need to enhance the display and content of their weblogs so that readers are more interested in their writings.
\end{abstract}

Keywords: Perception, Writing, Creative Writing, Weblog, Digital Fluency.

\section{INTRODUCTION}

Success in writing academically cannot be achieved instantly. For learners to master writing skills, they should acquire writing techniques such as choosing the right words and phrases, following the proper structure of writing; mastering vocabulary, grammar, punctuation, and many more [1]. The success of English Foreign Language (EFL) students depend on them becoming proficient in English. Thus, their ability to write is one of the skills needed for proficiency [2]. Besides, learners are required to do a lot of writing practices, understanding the theories of writing, and reading various written references. Therefore, to reach those skills, students need to learn writing from the basics with an engaging and exciting method, and one way of doing that is through creative writing in weblogs.

According to Dharma [3], learning writing can be done in two methods. The first one is called the traditional or offline method, in which students write a topic and submit the papers to be reviewed. This learning method is often overly dependent on teachers because the students need to receive feedback on their writing drafts. This type of learning might be ineffective for a large group of students and lead to boredom as learning often uses the old method. All the more, not all of the students' writing will get the feedback and assessment from the teacher and their classmate, consequently, the lack of feedback occurs. The second method is to utilize the Information Communication Technology (ICT) development in learning [3], such as using a weblog as a media in writing class. The use of weblogs has developed and become more popular with young students nowadays, as technology and modern lifestyle have been improved and advanced in time. Currently, weblogs are used for academic learning, where students exploit them as media to post their writings.

Weblogs (blogs) are personal web pages written in chronological order and maintained through a specific software that helps their administration [4]. This media has been used in some subjects, one of them is in Introduction to Creative Writing Subject 2019 of English Education Study Program, Jambi University. In this subject, fourth-semester students were asked to post their writings through the weblog. In the learning process, students are taught both non-fiction and fiction in creative writing.

This research observed deeper into what they think about the use of weblog and also how the weblog increases their writing skills to the next level. Moreover, the research provided a correlation between the use of weblogs and their writings, and how the students developed their abilities and creativity using weblogs.

\section{REVIEW OF RELATED LITERATURE}

Writing is one of the productive skills which produce a written product or information, besides reading, speaking, and listening as the four language skill to master in learning English [5]. Moreover, Brown [6], 
stated that a written product is a product of thinking, drafting, and revising that requires specialized skills, such as thinking about the goals of writing, make some points as brainstorming, organize them into a draft, writing the ideas coherently, edit the text for appropriate grammar, and produce writing as a final product.

Creative writing is non-formal writing in which the writers choose their material and forms. Writers use their imagination, ideas, and experiences to express their feelings and thoughts, even it is irrational [7]. In creative writing, the students can explore many aspects, such as writing a poem about their family, writing a short story, writing an essay based on their personal experience, and write a script writing for a play. In creative writing, it is allowed to use slang and abbreviations [8]. According to Donovan [9], there are two genres of creative writing, those are non-fiction: personal essay, biography, autobiography, editorial, film critiques, and travel writing, and fiction: prose (short stories, memoirs, novels, and drama), poetry, scriptwriting, journals, diaries, letters, essays, song lyrics, and vignettes [10]. In this research, the Introduction to Creative Writing Subject 2019 learns the whole genres and the lecturer gives some topics to the students. Moreover, the students are also free to choose what kind of sub-genres they want to write in weblogs.

Several experts define Weblog. According to Stauffer in Jones [2], a weblog or blog is a kind of online publishing software that has been useful for writing. Holtz in Alsubaie \& Madini [13], added this technological tool allows users to create and edit the content of their writing on the web page with minimal technical expertise and presented in reverse chronological order, with recent postings on the top and older postings pushed to the bottom [2]. Additionally, the content posted on the weblog is public or can be read by everyone. The common use of a weblog is as a personal online diary in which an individual submits their writings and gets comments from the audience [2]. Besides writing, weblogs are used to share photos, audio, and video clips. Weblogs can be used by a single person or many people putting up individual entries in a group blog. With the use of weblog, the students have the possibility of writing for a broader audience, not just to members of their class [2]. Nowadays, on the internet, many sites that provide services to create a weblog, such as Blogger, WordPress, Tumblr, Medium, and many more. Everyone can use it to create a personal weblog on these sites.

\section{RESEARCH METHODOLOGY}

This research used mixed methods to identify students' perception of creative writing in weblogs to improve their writing skills. The researcher took the population in sixth-semester students that have been completed the Introduction to Creative Writing subject in fourth-semester in English Education Study Program, Faculty of Teacher Training and Education at UNJA. To be more specific, the Introduction to Creative Writing class consists of 14 students in one class, so the population of this study is 14 students. In this research, the writer used two kinds of sampling, the first is total sampling, this sample is used for the quantitative data. Unfortunately, from 14 students, there was one student who did not fill the questionnaire, so there were 13 students from the Introduction to Creative Writing class who participated in filling the questionnaire. This number of samples follows the rules of sampling based on Slovin's formula which the sample $(n=13)$ is a viable minimum number of the total population $(\mathrm{N}=14)$. Then, for qualitative data, the writer used purposeful sampling (purposive sampling). The researcher selected 6 of 13 samples based on the strategies and phases [11].

Table 1. Frequency and Percentage Level of Students' Perception of Using Weblog in Their Writing

\begin{tabular}{|l|l|l|l|l|l|}
\hline \multirow{2}{*}{ No } & \multicolumn{1}{|c|}{ Statements } & \multicolumn{3}{c|}{ Frequencies of Response } \\
\cline { 3 - 6 } & & \multicolumn{1}{|c|}{$\begin{array}{l}\text { (SD) } \\
\text { (D) }\end{array}$} & \multicolumn{1}{|c|}{$\%$} & \multicolumn{1}{c|}{$\%$} & \multicolumn{1}{c|}{$\%$} \\
\hline 1 & $\begin{array}{l}\text { Writing on the Weblog made me use } \\
\text { academic writing style, register, and } \\
\text { vocabulary. }\end{array}$ & $\begin{array}{l}7,7 \\
(1)\end{array}$ & $\begin{array}{l}23,1 \\
(3)\end{array}$ & $\begin{array}{l}61,5 \\
(8)\end{array}$ & $\begin{array}{l}7,7 \\
(1)\end{array}$ \\
\hline 2 & $\begin{array}{l}\text { Writing on the Weblog made me more } \\
\text { careful about sentences and paragraphs. }\end{array}$ & 0 & $\begin{array}{l}7,7 \\
(1)\end{array}$ & $\begin{array}{l}30,8 \\
(4)\end{array}$ & $\begin{array}{l}61,5 \\
(8)\end{array}$ \\
\hline 3 & $\begin{array}{l}\text { Writing on the Weblog made me check } \\
\text { word choice and word spelling more } \\
\text { carefully. }\end{array}$ & 0 & $\begin{array}{l}7,7 \\
(1)\end{array}$ & $\begin{array}{l}30,8 \\
(4)\end{array}$ & $\begin{array}{l}61,5 \\
(8)\end{array}$ \\
\hline 4 & $\begin{array}{l}\text { Writing on the Weblog made me check } \\
\text { my grammar more carefully. }\end{array}$ & 0 & $\begin{array}{l}15,4 \\
(2)\end{array}$ & $\begin{array}{l}23,1 \\
(3)\end{array}$ & $\begin{array}{l}61,5 \\
(8)\end{array}$ \\
\hline 5 & $\begin{array}{l}\text { Writing on the Weblog made me carefully } \\
\text { revise the way I present my argument. }\end{array}$ & 0 & 0 & $\begin{array}{l}30,8 \\
(4)\end{array}$ & $\begin{array}{l}69,2 \\
(9)\end{array}$ \\
\hline
\end{tabular}

In this research, a close-ended questionnaire was used. This questionnaire was adopted from Fageeh [12] and Said, et al. [13]. In this study, the data collected by a survey online questionnaire on Google Form. For the interview, the researcher used an online interview using
WhatsApp Application and was held with 6 participants of 13 students. In quantitative data, the researcher analyzed the quantitative data and noted statistical results that need further information. Then, determined the purposeful sample by selected individuals who 
participated in the qualitative phase that can explain for further information. After that, the researcher prepared to design qualitative data collection procedures that identify the types of questions that need to be answered by the interviewee. After designing qualitative data collection procedures that identify the types of questions that need to be answered by the purposeful sample. The next steps were to collect and analyzed the qualitative data, developed a table that illustrates how the qualitative results enhance the information, and interpreted the value by the qualitative explanations.

Table 2. Frequency and Percentage Level of Students' Attitude toward Learning Writing Using Weblog

\begin{tabular}{|c|c|c|c|c|c|}
\hline \multirow{3}{*}{ No } & \multirow{3}{*}{ Statements } & \multicolumn{4}{|c|}{ Frequencies of Response } \\
\hline & & $1(\mathrm{SD})$ & $2(\mathrm{D})$ & $3(\mathrm{~A})$ & \multirow{2}{*}{$\frac{4(\mathrm{SA})}{\%}$} \\
\hline & & \multirow{2}{*}{$\%$} & $\%$ & $\frac{3(\mathrm{~A})}{\%}$ & \\
\hline 6 & $\begin{array}{l}\text { I enjoy writing on the Weblog for } \\
\text { developing my writing skills. }\end{array}$ & & $\begin{array}{l}7,7 \\
(1) \\
\end{array}$ & $\begin{array}{l}30,8 \\
(4) \\
\end{array}$ & $\begin{array}{l}61,5 \\
(8) \\
\end{array}$ \\
\hline 7 & $\begin{array}{l}\text { I think that my argumentation and } \\
\text { description in writing can be improved by } \\
\text { blogging on the internet. }\end{array}$ & 0 & 0 & $\begin{array}{l}61,5 \\
(8)\end{array}$ & $\begin{array}{l}38,5 \\
(5)\end{array}$ \\
\hline 8 & $\begin{array}{l}\text { Blogging is an effective way of learning } \\
\text { writing in English. }\end{array}$ & 0 & $\begin{array}{l}7,7 \\
(1)\end{array}$ & $\begin{array}{l}61,5 \\
(8)\end{array}$ & $\begin{array}{l}30,8 \\
(4)\end{array}$ \\
\hline 9 & $\begin{array}{l}\text { Blogging can improve the quality of my } \\
\text { writing. }\end{array}$ & 0 & 0 & $\begin{array}{l}61,5 \\
(8)\end{array}$ & $\begin{array}{l}38,5 \\
(5)\end{array}$ \\
\hline 10 & $\begin{array}{l}\text { Writing on a Weblog can motivate me } \\
\text { into more active and interactive in } \\
\text { writing. }\end{array}$ & 0 & 0 & $\begin{array}{l}61,5 \\
(8)\end{array}$ & $\begin{array}{l}38,5 \\
(5)\end{array}$ \\
\hline \multirow{3}{*}{ No } & \multirow{3}{*}{ Statements } & \multicolumn{4}{|c|}{ Frequencies of Response } \\
\hline & & $1($ SD) & $2(\mathrm{D})$ & $3(\mathrm{~A})$ & 4 (SA) \\
\hline & & $\%$ & $\%$ & $\%$ & $\%$ \\
\hline 1 & $\begin{array}{l}\text { Writing on the Weblog made me use } \\
\text { academic writing style, register, and } \\
\text { vocabulary. }\end{array}$ & $\begin{array}{l}7,7 \\
(1)\end{array}$ & $\begin{array}{l}23,1 \\
(3)\end{array}$ & $\begin{array}{l}61,5 \\
(8)\end{array}$ & $\begin{array}{l}7,7 \\
(1)\end{array}$ \\
\hline 2 & $\begin{array}{l}\text { Writing on the Weblog made me more } \\
\text { careful about sentences and paragraphs. }\end{array}$ & 0 & $\begin{array}{l}7,7 \\
(1)\end{array}$ & $\begin{array}{l}30,8 \\
(4)\end{array}$ & $\begin{array}{l}61,5 \\
(8)\end{array}$ \\
\hline 3 & $\begin{array}{l}\text { Writing on the Weblog made me check } \\
\text { word choice and word spelling more } \\
\text { carefully. }\end{array}$ & 0 & $\begin{array}{l}7,7 \\
(1)\end{array}$ & $\begin{array}{l}30,8 \\
(4)\end{array}$ & $\begin{array}{l}61,5 \\
(8)\end{array}$ \\
\hline 4 & $\begin{array}{l}\text { Writing on the Weblog made me check } \\
\text { my grammar more carefully. }\end{array}$ & 0 & $\begin{array}{l}15,4 \\
(2)\end{array}$ & $\begin{array}{l}23,1 \\
(3)\end{array}$ & $\begin{array}{l}61,5 \\
(8)\end{array}$ \\
\hline 5 & $\begin{array}{l}\text { Writing on the Weblog made me carefully } \\
\text { revise the way I present my argument. }\end{array}$ & 0 & 0 & $\begin{array}{l}30,8 \\
(4)\end{array}$ & $\begin{array}{l}69,2 \\
(9)\end{array}$ \\
\hline
\end{tabular}

\section{FINDINGS AND DISCUSSIONS}

\subsection{Students' Perception through Writing on Weblog}

Findings showed that all of the students prefer to used online writing in their writing class, in this term is a blog. Students felt blogs are helpful to intensify their writing, effective to develop creativity, encourage them to publish writing in a public environment, paperless, costeffective, expand their connection, and also provide motivation. As Student 4 mentioned in the interview: "Blogs help me to intensify my writing skills." (Student 4). Supported by the findings in the questionnaire, $61.5 \%$ of students strongly agreed that they enjoy writing on the weblog for developing their writing skills. As we know, writing is one of the basic language skills [5] which is important to master by the students for proficiency in learning English as Second Language [2]. Besides that, Weblogs also entertaining because it provides a variety of fun facilities, such as adding photos and videos, themes, and many more. These facilities encourage students to be "themselves" more because they designed their weblog, as the result the students feel comfortable having their personal space and they can also express their ideas in writing more freely with varied topics."The use of blogs can be used by students in expressing their writing ideas more freely, directed, and writing regularly with varied topics." (Student 6).

\subsection{The Way Weblog Help the Students in Improving Their Writing, Reading, and Others Skills}

Blogs have a big impact not only on students writing skills but also on students reading skills [14;2]. Blogs offer many reading and writing incentives for learning and writing because blogging emphasis on content, the possibility of speed feedback, the option of working with both words and images, and the ability to link one post to another, it also promotes benefits to students vocabulary and grammar [2]. $61.5 \%$ of students agreed weblog develops their writing skills, including improving 
argumentation and description, improve the quality of writing, and also active and interactive in writing. "Blogs helps to improve my writing skills because the more I write, the more I get used to it." (Student 1). There are several steps in writing, those are planning, prewriting, drafting, revising, editing, and publishing $[15 ; 6]$. All the students doing this process in their writing, from planning, thinking about the ideas and the information they choose to include [6]. In planning and prewriting, the students are looking for relevant data, browsing the topic on the internet, or discuss it with friends. Then, they make a rough draft to writing down the ideas and organized them into a coherent draft. Students save their draft on the weblog. Then, the students evaluate their writing by revising and editing, in these steps they mostly ask their friends to help them to read their writing and give them feedback to make sure whether they make a mistake or not. Supported by the findings, students strongly agreed $(69.2 \%)$ that weblog made them carefully revise the way they present their argument. Editing is the almost-final step, in these steps the students can produce a different result from the plan they made. The last is publishing those works on blogs.

Table 3. Frequency and Percentage Level of Students' Perception in Using Weblog Media in Introduction to Creative Writing

\begin{tabular}{|c|c|c|c|c|c|}
\hline \multirow{3}{*}{ No } & \multirow{3}{*}{ Statements } & \multicolumn{4}{|c|}{ Frequencies of Response } \\
\hline & & 1 (SD) & $2(\mathrm{D})$ & $3(\mathrm{~A})$ & 4 (SA) \\
\hline & & \multirow[t]{2}{*}{$\%$} & \multirow[t]{2}{*}{$\%$} & $\%$ & $\%$ \\
\hline 11 & $\begin{array}{l}\text { I think doing creative writing on the } \\
\text { Weblog has benefits to my writing skills. }\end{array}$ & & & $\begin{array}{l}53,8 \\
(7)\end{array}$ & $\begin{array}{l}46,2 \\
(6)\end{array}$ \\
\hline 12 & $\begin{array}{l}\text { I recommend Weblogs as a writing } \\
\text { medium in writing classes. }\end{array}$ & 0 & 0 & $\begin{array}{l}53,8 \\
(7)\end{array}$ & $\begin{array}{l}46,2 \\
(6)\end{array}$ \\
\hline No & $\begin{array}{c}\text { Statements } \\
\end{array}$ & & equen & f Respo & \\
\hline
\end{tabular}

The students learn incidentally and intentionally by reading various articles and any other writings provided by blogs. Incidental learning occurs in the absence of a conscious intention to learn, or when learners' attention is focused not on language learning, but to understand the material they engage with [7]. They often reading other people's work to get the idea or to know about some topic they want to write about. In this process, students learn incidentally, without them knowing, they adding insight by learning new other stuff. They get the new vocabulary and know how to arrange the sentence to make a good paragraph. Another process in reading is intentional learning, which is generally thought to occur when learners' attention is focused on acquiring new languages and it usually impacts on the area of vocabulary [7]. "Every time I write, I have to find reading sources. It can improve my reading skills." (Student 5).

This reading and writing habit, has impacted students' vocabulary and grammar. They regularly used the words they got from reading to their writing so that they enhance their vocabulary. In this study, students still lack grammar accuracy, they often used Grammar Checker such as Grammarly or used auto-correct in Microsoft Word. Sometimes, they asked their friend to revise their mistakes. This writing on blogs helps them to check their grammar online to minimalize human error. Findings also showed writing on weblog made the students more careful about a sentence, paragraph, word choice, spelling, and grammar $(61.5 \%)$

Blogs also improve students' confidence and motivation to publish their works in the public environment. Students know there will be readers to read their works, because of that they produce a higher quality of work than students who write only for the lecturer and classmate. As the result, they produce an online portfolio and become more motivated to write more [2]. "I am excited to see the readers' responses. It was just nice that at least someone reads it. (Student 1). Even though the first time, the students feel anxious and afraid that no one will read or likes their writings, but then after practice to writing and publishing regularly, they get used to it. Besides, it also affects their motivation in writing. "Having readers makes me motivated to write. Sometimes someone corrects my writing, so it motivates me to write." (Student 2).

Table 4. Frequency and Percentage Level of Negative Aspect or Barriers of Weblog

\begin{tabular}{|c|l|c|c|}
\hline No & $\begin{array}{l}\text { Negative Aspects } \\
\text { or Barriers }\end{array}$ & Frequency & Percentage \\
\hline 1 & $\begin{array}{l}\text { Connection } \\
\text { problem }\end{array}$ & 9 & 26.5 \\
\hline 2 & $\begin{array}{l}\text { Difficulty in } \\
\text { grammar accuracy }\end{array}$ & 7 & 20.6 \\
\hline 3 & $\begin{array}{l}\text { Feeling anxious } \\
\text { due to audience }\end{array}$ & 7 & 20.6 \\
\hline 4 & $\begin{array}{l}\text { Responsibility } \\
\text { burden }\end{array}$ & 4 & 11.8 \\
\hline 5 & Feeling bored in & 1 & 11.8 \\
\hline 6 & Consuming time & 2 & 5.9 \\
\hline 7 & $\begin{array}{l}\text { Difficulty } \\
\text { posting blogs }\end{array}$ & & \\
\hline
\end{tabular}

\subsection{The Advantages and Barriers in Using Weblogs in Engish Creative Writing Subject}

The findings of this study confirm several positive aspects of writing on weblog. The three most favorable aspects are improving writing skills, developing writing topics in more detail, and fun and interesting activity. 
Followed by learning new vocabulary, improving computing skills, improving reading comprehension and the last is the effective use of time. The findings of the interview supported the result of the questionnaire, in terms of improving computing skills, the students mentioned several aspects they learned in this study, for example learning how to operate blogs, using Grammar and Plagiarism Checker, and also Photo Editor when they need to add some pictures to their writing on the blog. This helps the student to be better-using technology, as a result, the digital fluency of the students builds. These results relate to the literature review $[14 ; 2 ; 16 ; 4]$.

Table 5. Frequency and Percentage Level of Positive Aspects of Weblogs

\begin{tabular}{|c|l|c|c|}
\hline No & Positive Aspects & Frequency & Percentage \\
\hline 1 & $\begin{array}{l}\text { Improving writing } \\
\text { skills }\end{array}$ & 10 & 25.6 \\
\hline 2 & $\begin{array}{l}\text { Developing writing } \\
\text { topics in more } \\
\text { detail }\end{array}$ & 8 & 20.5 \\
\hline 3 & $\begin{array}{l}\text { Fun and interesting } \\
\text { activity }\end{array}$ & 7 & 17.9 \\
\hline 4 & $\begin{array}{l}\text { Learning new } \\
\text { vocabulary }\end{array}$ & 4 & 10.3 \\
\hline 5 & $\begin{array}{l}\text { Improving } \\
\text { computing skills }\end{array}$ & $\begin{array}{l}\text { Improving reading } \\
\text { comprehension }\end{array}$ & 3 \\
\hline 7 & $\begin{array}{l}\text { Efficient use of } \\
\text { time }\end{array}$ & 3.7 \\
\hline
\end{tabular}

The students also face several obstacles in this learning, such as connection problems, difficulty in grammar accuracy, and feeling anxious due to the audience as the three most unlikeable of writing on weblog. Followed by feeling bored, responsibility burden, consuming time, and the last is difficulty in posting blogs.

\section{CONCLUSION AND SUGGESTION}

Based on the result of this research, it can be concluded that all of the students have a positive perception of the use of weblog in Creative Writing subject. The students felt the use of weblogs is helpful because weblog is effective to develop their writing and reading skills, it is also comfortable and easy to use, especially to revise the mistakes of writing. Moreover, weblogs provide fun facilities such as follow, like, comment, views, etc. The flexibility in designing themes and layouts is indispensable, so the students can explore their creativity to express themselves. The students stated that there are several advantages of the use of weblogs, those are improving writing skills and developing writing topic in more detail, as well as improving their vocabulary, grammar, and sentence structure. It also enhances the digital fluency of the students such as operating the blogs and introduce the students in using the supporting application, for instance, Grammar and
Plagiarism Checker for checking their mistakes in writing and using Photo Editor and Legal Photo Sites to add pictures to be included in their writing on the blog.

The result showed that the students needed online platform use in their writing subject because it is the effective use of time and paperless. Nevertheless, the use of this media still needs to be improved, for example, connection problems and difficulty in grammar accuracy which the students felt the most as an obstacle in this learning. Also, the students need to enhance the way they present their blogs so that the interest of readers will be improved and the chance for the audience to reach students' writing will be expanded.

Students also need to learn how to design their blog and importantly their writing is must readable and interesting for the readers. It is even better if the students are focus on the trending topics to gain viewers. Even though this study still has many flaws, the researcher hopes there will be future researchers to research this area. It will be great if future researchers can conduct a study on the teachers' perception of online writing subjects and how the students write for a professionalpaid platform of writing.

\section{AUTHORS' CONTRIBUTIONS}

The title "AUTHORS' CONTRIBUTIONS" should be in all caps.

\section{ACKNOWLEDGMENTS}

The title "ACKNOWLEDGMENTS" should be in all caps and should be placed above the references. The references should be consistent within the article and follow the same style. List all the references with full details.

\section{REFERENCES}

[1] Pratiwi, K. D. (2016). Students' Difficulties in Writing English (A Study at The Third Semester Students of English Education Program at University of Bengkulu Academic Year 20112012). Bengkulu: Universitas Bengkulu.

[2] Jones, S. J. (2006). Blogging and ESL Writing: A Case Study of How Students Responded to The Use of Weblogs as a Pedagogical Tool for The Writing Process Approach in a Community College ESL Writing Class. Texas: University of Texas.

[3] Dharma, M. (2016, October 27). Wordpress. Retrieved from Belajar Online vs Belajar Offline: www.weespeakinglanguageschool.com/belajaronline-vs-belajar-offline/\#

[4] Mora, S., \& Espinosa, S. (2007). The Use of Weblogs in Higher Education: Benefits and Barriers. Spain: University of Alicante. 
[5] Spratt, M., Pulverness, A., \& Williams, M. (2005). Teaching Knowledge Test. Cambridge: Cambridge University Press.

[6] Brown, H. D. (2001). Teaching by Principles: An Interactive Approach to Language Pedagogy. Second Ed. New York: Addison Wesley Longman.

[7] Dell, W. C. (1964). Creative Writing in the English Classroom. The English Journal, 53(7), 500-503.

[8] Oshima, A., \& Hogue, A. (2007). Introduction to Academic Writing. New York: Longman

[9] Donovan, M. (2015, October 15). Writing Forward. Retrieved February 18, 2020, from Writing Forward: https://www.writingforward.com/creativewriting/types-of-creative-writing

[10] Earnshaw, S. (2007). The Handbook of Creative Writing. Edinburgh: Edinburgh University.

[11] Alsubaie, A., \& Madini, A. A. (2018). The Effect of Using Blogs to Enhance the Writing Skills of English Language at Saudi University. Global Journal of Educational Studies, 13-28.

[12] Creswell, J. W., \& Clark, V. L. (2018). Designing and Conducting Mixed Methods Research. California: SAGE Publications, Inc.

[13] Fageeh, A. I. (2011). EFL Learners' Use of Blogging for Developing Writing Skills and Enhancing Attitudes Towards English Learning. Journal of Language and Literature, 2(1), 31-48.

[14] Said, N. E., Yunus, M., Doring, L. K., Asmi, A., Aqilah, F., \& Su Li, L. K. (2013). Blogging to Enhance Writing Skills: A Survey of Students' Perception and Attitude. Asian School Science, 95100.

[15] Hufakker, D. (2005). The Educated Blogger: Using Weblogs to Promote literacy in the Classroom. AACE Journal, 91-98.

[16] Utami, A. B. (2012). Improving Students' Writing Skills on Recount Texts through Collaborative Writing Technique. Yogyakarta: Universitas Negeri Yogyakarta.

[17] Arndt, H. L., \& Woore, R. (2018). Vocabulary Learning from Watching YouTube Videos and Reading Blog Posts. Language Learning \& Technology, 124-142 